Історико-політичні проблеми сучасного світу: Збірник наукових статей. - Чернівці: Чернівецький національний університет, 2020. - T. 42. - C. 196-203

DOI: $10.31861 / \mathrm{mhpi} 2020.42 .196-203$

УДК 94 (477)+322 “19”
Modern Historical and Political Issues: Journal in Historical \& Political Sciences. - Chernivtsi: Chernivtsi National University, 2020. - Volume. 42. - pp. 196-203 DOI: $10.31861 / \mathrm{mhpi} 2020.42 .196-203$

(с) Олексій Кошель ${ }^{1}$

\title{
Духовенство українських спархій Російської Православної Церкви в духовно-національному відродженні (1907-1914 рр.)
}

Після Першої російської революції 1905-1907 рр. в українських єпархіях Російської Православної Церкви (РПЦ) відбувається активізація і радикалізація церковно-реформаторського руху. Представники українського православного духовенства висувають на порядок денний вимоги демократизації релігійного життя, відокремлення церкви від російської імперської держави, повернення до принципів соборності в ії управлінні, тощо. В українській періодиці, суспільному житті, у виступах патріотично-налаштованих священиків розгорнулася активна агітація за масове запровадження української мови у світське та духовне життя. Важливим здобутком патріотично налаштованого духовенства стало рішення Подільського єпархіального з'їзду про звернення до Св. Синоду та отримання від нього дозволу на запровадження у Подільській духовній семінарії предметів з української мови, літератури та історії України. Церковнореформаторський рух досліджуваного періоду сформував основу і необхідні кадри для активної боротьби за автокефалію української православної церкви, яка реалізувалася в роки Української революції 1917-1921 рр.

Ключові слова: православне духовенство, національне відродження, Російська Православна Церква (РПЦ), автокефалія, українізація.

\section{The Clergy of Ukrainian Dioceses of the Russian Orthodox Church in Spiritual and National Revival (1907-1914)}

After the defeat of the First Russian Revolution of 1905-1907, the church-reform movement continued to develop and strengthen in the regions of sub-Russian Ukraine. Patriotic clergy sought to return national traditions, customs and rites to society and the laity, advocated further Ukrainization of religious and secular education, weakening or elimination of the Synod and the autocephaly of the Orthodox Church.

The period under study is characterized by the emergence of Ukrainian church periodicals, further work of the clergy on translations and editions of the Holy Scriptures, collections of sermons and prayer books in Ukrainian, the creation of Ukrainian libraries in religious schools, the activity of clergy in celebrating the anniversaries of Taras Shevchenko and their activity in "Prosvita". An important role was also played by the youth of religious educational institutions: during their protests the main demands were the issue of Ukrainianization of the educational process.

An important achievement of the patriotic clergy was the decision of the Podilsky Diocesan Congress on the appeal to the Holy Synod and obtaining permission from him to introduce subjects on the Ukrainian language, literature and history of Ukraine as extracurricular in the Podilsky orthodox theological seminaries.

Protests were important for the spiritual and national revival actions of religious youth in Podillia, Volyn, Poltava, Ekaterynoslav, Odessa theological seminaries and Kyiv orthodox theological academy. Among the main demands of the protesters there were the issues of holding church reforms, democratization of the educational process and implementation of the subjects for the study of Ukrainian history and literature.

\footnotetext{
${ }^{1}$ Кандидат історичних наук, докторант Чернівецького національного університету імені Юрія Федьковича, Україна. E-mail: koshel@cvu.kiev.ua; https://orcid.org/0000-0002-0347-328X.
} 
The struggle of the Orthodox clergy for the democratization and Ukrainization of the Orthodox Church in Ukraine in the period 1907-1914 became the main basis for strengthening the movement for the autocephaly of the church and formed its future personnel reserve.

Key words: Orthodox clergy, national revival, Russian Orthodox Church (ROC), autocephaly, ukrainization.

Постановка наукової проблеми та її значення. Питання участі православного духовенства в духовно-національному відродженні другої половини XIX - початку XX ст. потребують подальшого наукового дослідження. Зокрема важливими $\epsilon$ комплексне вивчення питань протестного та страйкового руху духовної молоді українських православних семінарій та Київської духовної академії, ролі патріотичних семінарських гуртків у цьому русі, вимог протестного руху щодо реформування церкви та українізації духовної освіти.

Аналіз останніх досліджень. Тема участі православного духовенства в духовнонаціональному відродженні другої половини XIX-початку XX ст. в історіографічному плані $\epsilon$ досить складною і недостатньо вивченою. Радянські історики у своїх працях передусім розглядали реакційну, антинародну діяльність православного духовенства. Однак роботи таких істориків як П.Зирянова ${ }^{2}$, Б.Титлінова ${ }^{3}$, О.Коломієць ${ }^{4}$ та ін. містять багатий фактологічний матеріал про участь представників духовенства в революційному та протестному русі досліджуваного періоду.

Праці релігієзнавців і науковців української еміграції 1920-80-х років відзначаються об'єктивністю висвітлення історії православної церкви та початків процесів ії українізації в другій половині XIX - на початку XX ст. Серед них варто відзначити роботи дослідження В.Липківського ${ }^{5}$, Д.Дорошенка ${ }^{6}$, I.Огієнка ${ }^{7}$, П.Табінського ${ }^{8}$ та ін. Однак, варто зазначити, що їх дослідження не могли включати багатого фактологічного матеріалу, якій знаходився в архівних установах України та Росії.

За роки незалежності України з'явилася низка узагальнюючих праць, які деталізують і враховують регіональні особливості виникнення опозиційного руху духовенства українських єпархій РПЦ. Серед них роботи В. Рожка ${ }^{9}$, А.Л. Зінченка ${ }^{10}$, В. Ровінського і О. Миханчука ${ }^{11}$, Т. Кузнець ${ }^{12}$ та ін.

Мета статті - проаналізувати роль духовенства українських єпархій РПЦ в духовнонаціональному відродженні 1907-1914 рр. Для цього передбачено вирішити такі головні дослідницькі завдання: проаналізувати головні вимоги, які висувалися молоддю духовних навчальних закладів під час протестних акцій, зокрема, щодо українізації навчального процесу; дослідити діяльність духовенства щодо пропаганди церковних реформ та українізації церкви в періодичних виданнях; проаналізувати процес становлення руху духовенства за автокефалію української церкви.

\footnotetext{
2 Зырянов П. (1994), Православная иеерковь в борьбе с революичией 1905-1907 г2., Москва, 1984, 224 с.

3 Титлинов Б. (1925), Молодежь и революиия. Из истории революционного движения среди учащейся молодежи духовных и средних учебных заведений. 1860-1905 г2., Ленинград, Госиздат, 166 с.; Б.Титлинов (1924), Церковь во время революиии, Петроград, Былое, 196 с.

${ }^{4}$ Коломієць О. (1973), Антиклерикальні виступи селян Правобережної України в 1900-1914 рр., Український історичний журнал, № 11, с. 108-115.

5 Липківський В. (1961), Історія Украӥнської православної иеркви, Вінніпег, Фундація Івана Грищука.

6 Дорошенко Д. (1940), Православна церква у минулому і сучасному житті, Берлін, 69 с.

7 Іларіон (митрополит) (1991), Українська культура і наша ичерква: ідеологія Української православної церкви, Вінніпег, тов-во «Волинь», 84 с.

8 Табінський П. (1937), Українське національне відродження і православне духовенство, Альманах «Нового часу», Львів, с. 72-79.

${ }^{9}$ Рожко В. (2002), Духовні православні освітні заклади Волині ХІХ-XX ст., Луцьк, 232 с.

10 Зінченко А. (1993), Благовістя національного духу (Украӥнська цчерква на Поділлі в першій третині ХХ cm.), Київ, 256 с.

11 Ровінський О., Миханчук О. (1995), Православ'я на Подолї: історичні нариси, Кам'янецьПодільський, б.в., 176 с.

12 Кузнець Т. (2006), Православне духовенство Уманщуини XIX-початку XX століття, Київ, вид.центр «Київ. ун-т», 607 с.
} 
Виклад основного матеріалу. Події Першої російської революції 1905-1907 рр. прискорили кризові явища в середовищі РПЦ, сприяли подальшому розширенню реформаторського руху та боротьби духовенства українських єпархій за використання української мови в освітній, культурній і духовній сфері. Зокрема, в українській періодиці, суспільному житті, у виступах патріотично налаштованих священиків розгорнулася активна агітація та популяризація необхідності масового запровадження української мови.

До 1911 р. у Кам’янці-Подільському продовжувала працювати редакційна комісія на чолі 3 єпископом Парфенієм по виданню рідною мовою Св. Письма за перекладом Морачевського. Загалом було видано 20 тисяч примірників перекладу, з яких понад 10 тисяч екземплярів потрапили у церкви, а інші до бібліотек закладів духовної освіти та мирян ${ }^{13}$. Значного поширення набуло видання перекладів українською мовою збірників молитов та церковних проповідей. Так, з благословення єпископа Парфенія у 1909 р. було видано збірку проповідей українською мовою подільського священиків П.Степанківського та К. Ванькевича ${ }^{14}$, а протоієрей А. Геращенко переклав рідною мовою 30 молитов і надіслав їх Синоду для розгляду ${ }^{15}$. Священик А. Гриневич видав у м. Балті Подільської губернії україномовний збірник богословських віршів «До Бога: Євангельські наголоси», який був схвально зустріло духовенство ${ }^{16}$.

Проте, далеко не всі представники духовенства українських єпархій РПЦ були прихильниками українізації духовного життя та здійснювали богослужіння та треби російською і церковнослов'янською мовами. На початку XX ст. у середовищі духовенства українських єпархій РПЦ діяли дві протилежні групи духовенства: 1) більша частина священиків і церковнослужителів, пройшовши тривалий час русифікації та денаціоналізації, підтримувала російське самодержавство, вищу церковну владу і виступала проти українських визвольних змагань та українізації духовного життя; 2) менша частина - стояла на українських патріотичних позиціях і чинила опір уніфікаційним заходам влади. Перша група в основному проживала в українських містах, які зазнали русифікації, друга - головним чином обслуговувала сільські парафії і була представлена сільським духовенством, яке було тісно зв'язане з українським народом, зберігало його національні традиції.

Носієм української національної ідеї в церковному середовищі була насамперед молодь, що навчалася в духовних семінаріях. Для багатьох семінаристів участь в українському національному русі була формою протесту проти закостенілості, схоластики і догматизму навчання в цих закладах духовної освіти. У 1907-1914 pр. семінаристи активно виступали за введення української мови в навчальний процес, запровадження вивчення рідної мови, літератури та історії України, влаштовували музичні вечори $з$ українськими піснями та Шевченківські читання, створювали українські бібліотеки у своїх навчальних закладах. Така діяльність відбувалася умовах постійних жандармських обшуків, арештів, поліційного нагляду й інших репресивних переслідувань за «неблагонадійну» діяльність семінаристів.

У цей період протестні акції мали місце у Подільській, Волинській, Полтавській, Катеринославській, Одеській духовних семінаріях та Київській духовній академії. Матеріали журналів учбового комітету при Св. Синоді свідчать, про те, що вплив на організацію акцій, зокрема протестів у Волинській духовній семінарії у 1909 і 1910 pp. мали семінаристи які характеризувалися як українофіли та духовна молодь, об'єднана у патріотичні гуртки ${ }^{17}$.

У 1906 р. Подільський єпархіальний з'їзд прийняв рішення щодо необхідності запровадження предметів з української мови, літератури та історії України в позанавчальний час. Відповідно до постанов з'їзду, у червні 1907 р. єпископ Подільський і Брацлавський Парфеній звернувся iз рапортом до Св. Синоду, де вказував, що «Подільська губернія заселена, головним чином,

\footnotetext{
${ }^{13}$ Мошак М. (1993), Четвероєвангеліє перекладу П. Морачевського. Шлях його видання, Культура Поділля: історія і сучасність, Хмельницький, Поділля, с. 112.

${ }^{14}$ Державний архів Хмельницької області (далі - ДАХМО), ф. Р-3333, оп. 1, спр. 18. Сіцінський Є. Листування про переклад Євангелія українською мовою. 1905-1912 рр., 117 арк.

15 Трембіцький А. (2015), Історія перекладу Четвероєвангелія Пилипа Морачевського в епістолярній спадщині Євфимія Сіцінського, Науковий потенціал славістики: історичні здобутки та тенденції розвит$\kappa y$, Київ, б.в., 2015, с. 206.

${ }^{16}$ Тригуб О. (2016), Єпископ УАПЦ Антон Гриневич (1875-1937), EMIНАК, № 3, Т.1, с. 46.

${ }^{17}$ Російський державний історичний архів, м.Санкт-Петербург (далі - РДІА), ф. 802, оп. 10, спр. 491. Про хвилювання у Волинській духовній семінарії. 1910 р., арк. 27.
} 
малоросами, яких тут два 3 половиною мільйони, або 81\% всього населення, а пасторам церкви необхідно знати літературу та історію народу, серед якого вони священствують» та клопотав про «запровадження серед курсів наук в останніх двох класах Подільської духовної семінарії предметів викладання малоросійської (української) літератури й історії Поділля та України» ${ }^{18}$. Наслідком цього клопотання стало прийняття у серпні 1907 відповідного рішення Св. Синоду, яким було надано дозвіл викладання цих предметів «у старших класах Подільської семінарії в позакласний час та за місцеві кошти» ${ }^{19}$.

У грудні 1908 р. на черговому Подільському єпархіальному з'їзді було вирішено підтримати фінансування підготовки збірок молитов та проповідей українською мовою, а також продовжити асигнування на викладання української мови, літератури та історії України в Подільській духовній семінарії ${ }^{20}$. Активний прихильник українізації православної церкви, подільський протоієрей Ю.Сіцінський в листі до відомого українського історика О.Левицького писав: «У нашій семінарії дозволено читати, як необов'язковий предмет, історію української літератури, історію України і Поділля на місцеві кошти. Спархіальний з'їзд асигнував лектору 1500 руб. на рік i призначено одночасно на придбання книг 400 руб... Затримка тепер за лекторами» ${ }^{21}$.

Патріотично налаштовані представники українського духовенства, молодь духовних закладів освіти та мирян брали активну участь у вшануванні національних героїв, відомих українських літераторів, діячів національно-культурного відродження. Яскравим прикладом $є$ їх участь у відзначенні всупереч заборони самодержавною владою разом з українським товариством «Просвіта» у 1911 р. 50-тих роковин $з$ дня смерті та в 1914 р. - 100-річчя від дня народження Тараса Шевченка.

Відверто негативну позицію щодо вшанування пам'яті Шевченка зайняв ряд єпископатів Російської православної церкви. Загальновідомим $є$ факт клопотання харківського архієпископа Арсенія (Брянцева) перед харківським губернатором і Синодом про заборону «Кобзаря» і вилучення його зі складів і бібліотек. У лютому 1911 р. міністр внутрішніх справ задовольнив це клопотання, наказавши переслідувати його видавців ${ }^{22}$.

У відповідності до рішення Правління Подільської духовної семінарії у грудні 1913 р. єпископ Подільський Серафим звернувся з клопотанням до Св. Синоду про святкування у семінарії 100-річчя з дня народження Тараса Шевченка. У листі він вказав на необхідність врахування позиції вихованців семінарії, які прихильно ставляться до творчості поета і запропонував вшанувати його пам'ять «служінням панахиди у семінарському храмі, облаштуванням у вечірні часи читання з виконанням вихованцями окремих віршів поета, дорученням старому викладачеві громадянської історії скласти і прочитати для вихованців біографію і літературний огляд творів Шевченка» ${ }^{23}$. У відповідь на звернення 25 січня 1914 р. рішенням Св. Синоду було наказано, зокрема, Преосвященним Подільському, Волинському, Катеринославському, Митрополитам Київському, Полтавському, Харківському та Херсонському вжити заходів для недопущення в єпархіях урочистих панахид та зібрань у духовно-учбових закладах, присвячених пам'яті Шевченка ${ }^{24}$.

Заборона відзначення 100-річчя від дня народження Тараса Шевченка викликала обурення і хвилю протестів у прогресивної громадськості України. На Поділлі ювілей поета був відзначений протестними виступами студентів і учнів, читанням його творів у Подільській духовній семінарії, молодіжних гуртках. У відповідь на нелегальне відзначення ювілею Т.Г. Шевченка кам’янецькі жандарми у ніч з 16 на 17 травня 1914 р. провели обшуки на квартирах чільних ді-

\footnotetext{
18 РДІА, ф. 802, оп. 10, спр. 70. Про запровадження викладання малоросійської мови та літератури в 5 і 6 класах Подільської духовної семінарії. 1914 р., арк. 1.

19 Там само, арк. 5.

${ }^{20}$ Опря А. (2008), Православне духовенство в реформаційному та національно-визвольному русі України (1900 - лютий 1917 рр.), Кам'янець-Подільський, Оіюм, с. 75

${ }^{21}$ Постаті в листах: епістолярій Юхима Сіцінського (2014), Київ, Старий світ, с. 218

${ }^{22}$ Гладкий С. (1995), Культурницька діяльність парафіяльного духовенства православних єпархій України початку XX cm., Запоріжжя, вид-во Запорізького держ. ун-ту, с. 9.

${ }^{23}$ РДІА, ф. 796, оп. 198, відд. 2, спр. 30. Про запровадження викладання малоросійської мови та літератури в 5 і 6 класах Подільської духовної семінарії. 1914 р., арк. 4.

${ }^{24}$ РДІА, ф. 387, оп. 198, відд. 1, спр. 30. Про святкування дня пам'яті поета Шевченка в Подільській духовній семінарії. 1907 р., арк. 6.
} 
ячів «Просвіти», у Подільській семінарії й знайшли видання «Кобзаря» Шевченка та багато іншої україномовної літератури, в тому числі забороненої. Наслідком цього стало проведення слідчих дій над учасниками зібрання зі вшанування ювілею Тараса Шевченка в духовній семінарії і встановлення поліційного нагляду за ними ${ }^{25}$.

Владні структури висловлювали стурбованість постійним зростанням проукраїнських настроїв у середовищі православного духовенства. Так полтавський губернатор Карл Багговут у секретному донесенні міністру внутрішніх справ за 1914 рік зазначав: «Сільське духовенство у значній мірі також співчуває українському рухові, і оскільки воно найбільш близько стоїть до сільського населення, то через посередництво духовенства ідеї ці легше проникають у простий народ. Духовенство поки відкрито не виступає, але ні скільки не чинить опору руху і у всякому зручному випадку дає зрозуміти народові, що він має власну мову і власну історію» ${ }^{26}$.

Загалом, не зважаючи на зусилля офіційної влади та Синоду, частина українського кліру все більше підтримувала церковні реформи та процес українізації церковного і світського життя. Після Першої російської революції 1905-1907 pр. патріотично налаштоване духовенство та церковнослужителі виносили на порядок денний питання необхідності послаблення влади Синоду, підвищення в системі управління українською православною церквою ролі місцевих духовних структур, надання українському православ’ю автономії в межах РПЦ та автокефалії української церкви. Депутат II Державної думи священик з Поділля А.Гриневич виступив з публікаціями у думській пресі, в яких обгрунтовував необхідність автокефалії церкви, яка стане «вільною церквою для вільного народу» ${ }^{27}$. У 1911 р. через газету «Рада» священик А.С-вський звертався до громадськості України з радикальним закликом: «Нам, українцям, потрібна Українська православна церква, як білорусам Білоруська» ${ }^{28}$.

Одним із важливих здобутків революції 1905-1907 рр. стала поява україномовної періодики та часткового зменшення впливу цензури у державних та духовних російськомовних часописів, що видавалися в Україні. У 1905 р. у Києві почала виходити перша україномовна щоденна політична, економічна і літературна газета «Громадська думка», фундаторами якої стали відомі діячі національного відродження Є.Чикаленко, С.Єфремов та В.Леонтович. У 1906 і до 1914 pp. - став видаватися популярний україномовний часопис «Рада», який займав провідну роль 3поміж українських періодичних видань. На своїх шпальтах «Рада» висвітлювала 3 ліберальних позицій різноманітні події з українського життя, у тому числі духовного, була трибуною для дебатів щодо проектів державних і церковних реформ та перетворень $\mathrm{i}$, таким чином, формувала національну свідомість серед широких кіл українського населення і мирян ${ }^{29}$.

Українська фракції II Державної думи у 1907 р. започаткувала видання у Петербурзі двох україномовних газет «Рідна справа», «Думські вісті», які інформували читачів про парламентське життя, обговорювали різні законопроектів, в тому числі щодо церковного життя, формували громадську думку.

Водночас упродовж 1905-1914 рр. продовжували видаватися суспільно-політичні газети «Православная Подолия», «Волынь», «Вестник Волыни», «Жизнь Волыни», «Волынские епархиальные ведомости», «Киевская газета», «Киевские епархиальные ведомости», «Одесские новости» та інші видання. Вони активно використовувалися як консервативною, так і ліберальною частиною духовенства. У виданнях пропагувалися як церковні реформи, так і контрреформи, висвітлювали «за» і «проти» процесу українізації суспільного і духовного життя. Однак,

\footnotetext{
${ }^{25}$ РДІА, ф. 387, оп. 198, відд. 1, спр. 30. Про святкування дня пам'яті поета Шевченка в Подільській духовній семінарії. 1907 р., арк. 4.

${ }^{26}$ Гладкий С. (1995), Вказ. пр., с. 41.

27 Опря А. (1996), Антон Гриневич, Тези доповідей n'ятнадиятої Вінницької обласної історикокраєзнавчої конференції, Вінниця, с. 59.

${ }_{28}$ Меша В. (2004), Українське національне відродження 1905-1914 років (Історіографія проблеми), Київ, Либідь, с. 27

${ }^{29}$ Трембіцький А. (2005), Статті - огляди церковної періодики Є. Сіцінського - цінне історичне джерело дослідження церковно-етнічної культури українців, Українська періодика: історія і сучасність, Львів, НАН України, ЛНБ ім. В. Стефаника, с. 256-261.
} 
вони значною морою впливали на поширення ідей церковних реформ, автономії та автокефалії української церкви ${ }^{30}$.

Висновки. Не зважаючи на ці досягнення, рух українського духовенства за національнодуховне відродження до часу Першої світової війни і до початку лютневої революції 1917 року так і не спромігся офіційно поставити питання про відокремлення, незалежність від РПЦ українського православ'я. Однак, активна діяльність церковно-ліберального табору та патріотичноналаштованого духовенства 3 представниками ортодоксально-консервативної течії підривала єдність православної церкви, була важливим фактом її дезорганізації.

Водночас, патріотично налаштоване духовенство проводило активну роботу з популяризації української мови, зокрема, через видання збірок проповідей, молитов, богословських віршів, запровадження в навчальний процес курсів української літератури та історії України. Важливим здобутком духовенства стала їх активна участь у відзначенні спільно з товариством «Просвіта» у 1911 р. 50-тих роковин $з$ дня смерті та в 1914 р. - 100-річчя від дня народження Тараса Шевченка. Через публікації у періодичних виданнях на порядок денний були винесені питання необхідності послаблення влади Синоду, підвищення ролі місцевих духовних структур в системі управління православною церквою, надання українському православ'ю автономії в межах РПЦ та автокефалії церкви.

Весь період боротьби за демократизацію та українізацію православної церкви у другій половині XIX - на початку XX ст. став підгрунтям появи руху за автокефалію української церкви. Важливим здобутком періоду початку XX ст. стала підготовка плеяди національно свідомих церковних діячів які стали активними діячами та лідерами цього руху.

\section{Список джерел}

1. Гладкий С. (1995) Культурницька діяльність парафіяльного духовенства православних єпархій Украӥни початку XX ст., Запоріжжя, вид-во Запорізького держ. ун-ту, 49 с.

2. Денисенко В. (2004), Часопис «Киевские епархиальные ведомости» в історії національно-духовного життя Украӥни (1861-1918 рр.), автореф. дис. канд. істор. наук, Київ, 22 с.

3. Державний архів Хмельницької області (далі - ДАХМО), ф. Р-3333, оп. 1, спр. 18. Сіцінський С. Листування про переклад Свангелія українською мовою. 1905-1912 рр., 117 арк.

4. Дорошенко Д. (1940), Православна церква у минулому і сучасному житті, Берлін, 69 с.

5. Зінченко А. (1993), Благовістя національного духу (Українська церква на Поділлі в першій третині ХХ ст.), Київ, 256 с.

6. Зырянов П. (1994), Православная церковь в борьбе с револючией 1905-1907 г2., Москва, 1984, 224 c.

7. Іларіон (митрополит) (1991), Украӥнська культура і наша цеерква: ідеологія Украӥнської православної церкви, Вінніпег, тов-во «Волинь», 84 с.

8. Коломієць О. (1973), Антиклерикальні виступи селян Правобережної України в 19001914 рр., Украӥнський історичний журнал, № 11, с. 108-115.

9. Кузнець Т. (2006), Православне духовенство Уманщини ХІХ - початку XX століття, Київ, вид.центр «Київ. ун-т», 607 с.

10. Липківський В. (1961), Історія Украӥнської православної церкви [The History of the Ukrainian Orthodox Church], Вінніпег, Фундація Івана Грищука.

11. Меша В. (2004), Украӥнське національне відродження 1905-1914 років (Історіографія проблеми), Київ, Либідь, 178 с.

12. Мошак М. (1993), Четвероєвангеліє перекладу П. Морачевського. Шлях його видання, Культура Поділля: історія і сучасність, Хмельницький, Поділля, с. 112.

13. Опря А. (1996), Антон Гриневич, Тези доповідей n'ятнадиятої Вінницької обласної історико-краєзнавчої конференщї, Вінниця, с. 59-60.

14. Опря А. (2008), Православне духовенство в реформаційному та національновизвольному русі Украӥни (1900 - лютий 1917 рр.), Кам'янець-Подільський, Оіюм, 191 с.

15. Постаті в листах: епістолярій Юхима Сіцінського (2014), Київ, Старий світ, 320 с.

16. Ровінський О., Миханчук О. (1995), Православ'я на Подолії: історичні нариси, Кам'янець-Подільський, б.в., 176 с.

\footnotetext{
30 Денисенко В. (2004), Часопис «Киевские епархиальные ведомости» в історії національно-духовного життя України (1861-1918 рр.), автореф. дис. канд. істор. наук, Київ, 22 с.
} 
17. Російський державний історичний архів, м.Санкт-Петербург (далі - РДІА), ф. 387, оп. 198, відд. 1, спр. 30. Про святкування дня пам'яті поета Шевченка в Подільській духовній семінарії. 1907 р., арк. 6.

18. РДІА, ф. 387 , оп. 198, відд. 1, спр. 30. Про святкування дня пам'яті поета Шевченка в Подільській духовній семінарії. 1907 р., арк. 4.

19. РДІА, ф. 796, оп. 198, відд. 2, спр. 30. Про запровадження викладання малоросійської мови та літератури в 5 і 6 класах Подільської духовної семінарії. 1914 р., арк. 4.

20. РДІА, ф. 802, оп. 10, спр. 491. Про хвилювання у Волинській духовній семінарії. 1910 р., арк. 27.

21. РДІА, ф. 802, оп. 10, спр. 70. Про запровадження викладання малоросійської мови та літератури в 5 і 6 класах Подільської духовної семінарії. 1914 р., арк. 1.

22. РДІА, ф. 802, оп. 10, спр. 70. Про запровадження викладання малоросійської мови та літератури в 5 і 6 класах Подільської духовної семінарії. 1914 р., арк. 5.

23. Рожко В. (2002), Духовні православні освітні заклади Волині XIX - XX ст., Луцьк, 232 с.

24. Табінський П. (1937), Українське національне відродження і православне духовенство, Альманах «Нового часу», Львів, с. 72-79.

25. Титлинов Б. (1925), Молодежь и револючия. Из истории револючионного движения среди учащейся молодежи духовных и средних учебных заведений. 1860-1905 г2., Ленинград, Госиздат, $166 \mathrm{c}$.

26. Титлинов Б. (1924), Церковь во время революиии, Петроград, Былое, 196 с.

27. Трембіцький А. (2005), Статті - огляди церковної періодики Є. Сіцінського - цінне історичне джерело дослідження церковно-етнічної культури українців, Українська періодика: icторія і сучасність, Львів, НАН України, ЛНБ ім. В. Стефаника, с. 256-261.

28. Трембіцький А. (2015), Історія перекладу Четвероєвангелія Пилипа Морачевського в епістолярній спадщині Свфимія Сіщінського, Науковий потенціал славістики: історичні здобутки та тенденції розвитку, Київ, б.в., 2015, с. 204-206.

29. Тригуб О. (2016), Єпископ УАПЦ Антон Гриневич (1875-1937), EMIНАК, № 3, Т.1, с. 44-51.

\section{References}

1. Hladkyj S. (1995) Kul'turnyts'ka diial'nist' parafiial'noho dukhovenstva pravoslavnykh ieparkhij Ukrainy pochatku XX st. [Cultural activity of the parish clergy of the Orthodox dioceses of Ukraine in the early twentieth century], Zaporizhzhia, vyd-vo Zaporiz'koho derzh. un-tu, $49 \mathrm{~s}$.

2. Denysenko V. (2004), Chasopys "Kyevskye eparkhyal'nye vedomosty» $v$ istorii natsional'nodukhovnoho zhyttia Ukrainy (1861-1918 rr.) [Magazine "Kyiv Diocesan Journalu" in the history of national and religious life of Ukraine (1861-1918)], avtoref. dys. kand. istor. nauk, Kyiv, $22 \mathrm{~s}$.

3. Derzhavnyj arkhiv Khmel'nyts'koi oblasti, f. R-3333, op. 1, spr. 18. Sitsins'kyj Ye. Lystuvannia pro pereklad Yevanheliia ukrains'koiu movoiu. 1905-1912 rr., 117 ark.

4. Doroshenko D. (1940), Pravoslavna tserkva u mynulomu i suchasnomu zhytti [The Orthodox Church in past and present life], Berlin, $69 \mathrm{~s}$.

5. Zinchenko A. (1993), Blahovistia natsional'noho dukhu (Ukrains'ka tserkva na Podilli v pershij tretyni XX st.) [The Gospel of the National Spirit (Ukrainian church in Podillia in the first third of the 20th century)], Kyiv, $256 \mathrm{~s}$.

6. Zyrianov P. (1994), Pravoslavnaia tserkov'v bor'be s revoliutsyej 1905-1907 hh. [The Orthodox Church in the struggle against the revolution of 1905-1907], Moskva, Nauka, 224 s. [in Russian].

7. Ilarion (mytropolyt) (1991), Ukrains'ka kul'tura i nasha tserkva: ideolohiia Ukrains'koi pravoslavnoi tserkvy [Hilarion (Metropolitan). Ukrainian culture and our church: Ideology of Ukrainian Orthodox Church], Vinnipeh, tov-vo «Volyn'», 84 s.

8. Kolomiiets' O. (1973), Antyklerykal'ni vystupy selian Pravoberezhnoi Ukrainy v 1900-1914 rr. [Anti-clerical riots of the peasants of the Right Bank Ukraine in 1900-1914] in Ukr. istor. zhurn, № 11, s. 108-115.

9. Kuznets' T. (2006), Pravoslavne dukhovenstvo Umanschyny XIX - pochatku XX stolittia [Orthodox clergy of Uman region in the XIX - beginning of the XX century], Kyiv, vyd.tsentr «Kyiv. un-t», $607 \mathrm{~s}$.

10. Lypkivs'kyj V. (1961), Istoriia Ukrains'koi pravoslavnoi tserkvy [The History of the Ukrainian Orthodox Church], Vinnipeh, Fundatsiia Ivana Hryschuka. 
11. Mesha V. (2004), Ukrains'ke natsional'ne vidrodzhennia 1905-1914 rokiv (Istoriohrafiia problemy) [Ukrainian national revival of 1905-1914 (Historiography of the problem)] Kyiv, Lybid', $178 \mathrm{~s}$.

12. Moshak M. (1993), Chetveroievanheliie perekladu P. Morachevs'koho. Shliakh joho vydannia [The Four Gospels translated by P. Morachevsky, The way of its publication.] in Kul'tura Podillia: istoriia i suchasnist'. Materialy druhoi naukovo-praktychnoi konferentsii, Khmel'nyts'kyj, Podillia, s. 112.

13. Opria A. (1996), Anton Hrynevych [Anton Hrynevich] in Tezy dop. p'iatnadtsiatoi Vinnyts'koi oblasnoi istoryko-kraienachoi konferentsii 14 travnia 1996 r., Vinnytsia, s. 59-60.

14. Opria A. (2008), Pravoslavne dukhovenstvo v reformatsijnomu ta natsional'no-vyzvol'nomu rusi Ukrainy (1900 - liutyj 1917 rr.) [Orthodox clergy in the Reformation and national liberation movement of Ukraine (1900 - February 1917)], Kam'ianets'-Podil's'kyj, Oiium, 191 s.

15. Postati v lystakh: epistoliarij Yukhyma Sitsins'koho [Personalities in the letters: the epistolary of Yukhim Sitsinsky] (2014), uporiad., komentari: OM. Koshel', V.S. Prokopchuk, I.O. Staren'kyj, Kyiv, Staryj svit, 320 s.

16. Rovins'kyj O., Mykhanchuk J. (1995), Pravoslav'ie na Podolii: istorychni narysy [Orthodoxy in Podolia: historical essays], Kam'ianets'-Podil's'kyj, b.v., 176 s.

17. Rosijs'kyj derzhavnyj istorychnyj arkhiv, m.Sankt-Peterburh (dali - RDIA), f. 387, op. 198, vidd. 1, spr. 30. Pro sviatkuvannia dnia pam'iati poeta Shevchenka v Podil's'kij dukhovnij seminarii. 1914 r., ark. 1-6.

18. RDIA, f. 387 , op. 198, vidd. 1, spr. 30. Pro sviatkuvannia dnia pamiati poeta Shevchenka v Podilskii dukhovnii seminarii. 1907 r., ark. 4.

19. RDIA, f. 796, op. 198, vidd. 2, spr. 30. Pro zaprovadzhennia vykladannia malorosiiskoi movy ta literatury v 5 i 6 klasakh Podilskoi dukhovnoi seminarii. 1914 r., ark. 4.

20. RDIA, f. 802, op. 10, spr. 491. Pro khvyliuvannia u Volynskii dukhovnii seminarii. 1910 r., ark. 27.

21. RDIA, f. 802 , op. 10 , spr. 70. Pro zaprovadzhennia vykladannia malorosiiskoi movy ta literatury v 5 i 6 klasakh Podilskoi dukhovnoi seminarii. 1914 r., ark. 1.

22. RDIA, f. 802 , op. 10, spr. 70. Pro zaprovadzhennia vykladannia malorosiiskoi movy ta literatury v 5 i 6 klasakh Podilskoi dukhovnoi seminarii. 1914 r., ark. 5.

23. Rozhko V. (2002), Dukhovni pravoslavni osvitni zaklady Volyni XIX - XX st. [Religious Orthodox educational institutions of Volyn XIX-XX centuries], Luts'k, $232 \mathrm{s.}$

24. Tabins'kyj P. (1937) Ukrains'ke natsional'ne vidrodzhennia i pravoslavne dukhovenstvo [Ukrainian national revival and Orthodox clergy] in Al'manakh «Novoho chasu», L'viv, s. 72-79.

25. Tytlynov B. (1925) Molodezh' y revoliutsyia. Yz ystoryy revoliutsyonnoho dvyzhenyia sredy uchaschejsia molodezhy dukhovnykh y srednykh uchebnykh zavedenyj. 1860-1905 hh. [Youth and revolution. From the history of the revolutionary movement among young students of religious and secondary schools. 1860-1905], Lenynhrad, Hosyzdat, 166 s. [in Russian].

26. Tytlynov B. (1924), Tserkov' vo vremia revoliutsyy [The church in the time of revolution], Petrohrad, Byloe, 196 s. [in Russian].

27. Trembits'kyj A. (2005), Statti - ohliady tserkovnoi periodyky Ye. Sitsins'koho - tsinne istorychne dzherelo doslidzhennia tserkovno-etnichnoi kul'tury ukraintsiv [Articles - reviews of church periodicals by E. Sitsinsky - a valuable historical source for the study of church and ethnic culture of Ukrainians] in Ukrains'ka periodyka: istoriia i suchasnist': dop. ta povidoml. dev'iatoi vseukr. nauk.teoret. konf., L'viv, NAN Ukrainy, LNB im. V. Stefanyka, s. 256-261.

28. Trembits'kyj A. (2015), Istoriia perekladu Chetveroievanheliia Pylypa Morachevs'koho v epistoliarnij spadschyni Yevfymiia Sitsins'koho [The history of the translation of the Four Gospels of Philip Morachevsky in the epistolary legacy of Euthymiy Sitsinsky] in Naukovyj potentsial slavistyky: istorychni zdobutky ta tendentsii rozvytku: tezy dopovidej Mizhnar. nauk. konf. do Dnia slov'ians'koi pysemnosti i kul'tury, Kyiv, s. 204-206.

29. Tryhub O. (2016), Yepyskop UAPTs Anton Hrynevych (1875-1937) [Bishop of the Ukrainian Autocephalous Orthodox Church Anton Hrynevych (1875-1937)] in EMINAK. Nauk. schokvartal'nyk № 3, t.1, s. 44-51. 